\title{
EVENTUAL VOLUNTARY MOTIVATION IN SPORTS IN YOUTH SCHOOL GAMES IN BRAZIL
}

\author{
H.A PEREIRA ${ }^{1}$, C.E. CAVALCANTE ${ }^{2}$ \\ Universidade Federal da Paraíba ${ }^{1,2}$ \\ helioaraujop@gmail.com ${ }^{1}$
}

Artigo submetido em 20/06/2018 e aceito em 09/08/2019

DOI: $10.15628 /$ holos.2019.7411

\section{ABSTRACT}

This article aims to identify motivational factors in possible volunteers who are involved in sporting events here in Brazil. The empirical data was collected based on the theoretical model of Bang and Chelladurai (2009) that began the development of the theoretical basis in the Olympic Games of Athens 2004. One quantitative research method was used by applying 167 question forms filled out by volunteers involved in the Youth Games. The research showed that the main motivational factors for sports in Paraíba are related to the following variables, in this order: expression of values, love of sports and interpersonal contacts. It was observed that the motivational, extrinsic variable was less relevant for the volunteers.

Key-words: Motivational factors. Eventual volunteer. Sporting. Youth games

\section{INTRODUCTION}


Voluntary work in Brazil goes back to the 16th century, assisting the needy people influenced by the Portuguese model of the houses of mercy. The main function was to provide medical care, food and shelter for those most in need (FALEIROS, 1995). As time went by, volunteer work spread to many areas in society, among them volunteer work in sport events (INTERNATIONAL OLYMPIC COMMITTEE - IOC (2016) and FÉDERATION INTERNATIONALE DE FOOTBALL ASSOCIATION - FIFA (2014)).

Eventual volunteers in sports, contribute meaningfully to the organization and success to events related to sport area. According to Pereira and Cavalcante (2018), more than 50 thousand volunteers acted in Olympic Games in Rio de Janeiro, assisting in many activity types in that event. These volunteers can work in the safety of sporting events, with the press, in the sports complex, in the medical area, in the food sector, helping the general organization (AÑO, 2003). With regard to youth games, most of the volunteers performed their activities in the logistics of the competition and assisted the organization in the competition venues.

This research aims to identify eventual volunteer motivational factors that has acted during the youth games held on João Pessoa city, in the year 2016. For this, theoric model developed by Bang and Chelladurai (2009) has been taken as a reference, in which they investigate motivation in volunteer work in sport events, from six variables: "expression of values", "interpersonal contact", "career orientation", "personal development", "extrinsic" and "love to sport".

Based upon the premises that this theoretic model is plenty used in research in other countries, and, considering that in Brazil, it was applied only in Pereira and Cavalcante's (2018) research in the Olympic Games in Rio de Janeiro, we have opted by its use in this research as a way to identify which are volunteer motivations from Paraíba State citizens, who have acted during the Youth Games in João Pessoa-PB, which has had volunteers from all over Paraíba State.

In Pereira and Cavalcante (2018) study, it was identified that main volunteer motivational factors in the Olympic Games in Rio de Janeiro are related to the following: "expression of values", "love to sport" and "interpersonal contacts". Johnston and Twynam (1998) researched the volunteer motivations in curling female championship 
in Canada. The result of this research showed that the main motivational factor in this event was the intention to be a volunteer.

A similar study about motivation in volunteer work towards sport was made by Gravilov (2012), in which volunteer motivational factors had been identified during Olympic Games in London, 2012. This author concluded that the main volunteer motivational factors are two-fold, being involved with sports and a sense of national pride.

Concerning to Paraíba, it is perceived that it is a State in which many sport events are held every year. For instance Paraíba hosts: Brazilian Beach Volleyball League games, Brazilian swimming championship, school games, and others. Understanding volunteer motivations in sport can contribute with the organizers of these events, relating to their management and volunteer recruitment, fulfilling a known gap of research in this area.

This gap could be made evident through a research performed in October 2017, with the expression "Volunteer work motivation in sport", in CAPES (Coordination for the Improvement of Higher Education Personnel) website. This research website comprises the more relevant magazines related to academic research. From this research we selected 258 articles about volunteer work, but in none of them, there was any relation with volunteer work motivation in sport in Paraíba, which is proposed in this article.

One of the greatest challenges for organizations that work with volunteers is to find a balance in management of available human capital (HALLMANN and HARMS, 2012). To carry out any management task, it is crucial to have data that may contribute with the process of taking decision towards the management of volunteer work. In practical terms, this research may subsidize managers that are in charge to organize sport events in Paraíba to understand volunteer motivational aspects related to this sport event, Youth School Games.

Youth School Games was a sport event held on between 08th and 15th November 2017, in João Pessoa, Paraíba, and gathered students from all Brazilian States in many sport modalities. With Youth School Games happening in the State of Paraíba, the perfect environment to perform this research would be set, due to fact of the alignment of this sport event with the aim of this article. Besides propitious, this 
research showed to be also viable from a literature that allowed to collect and analyze data pertinent to the research.

\section{THEORETICAL REFERENTIAL}

\section{VOLUNTEER WORK MOTIVATION}

About volunteer work context, theories used to understand volunteer motivation are another ones, different from theories about motivation in the scope of Administration, and its use is justified by the difference that volunteer worker has relating to formal worker (CAVALCANTE, 2012).

Volunteer work can be seen as an alternative to keep social order, in which a person acts as an agent of joint transformation. It can be also thought on how the transforming potential through these activities can represent to inner growth of every individual and to society transformation. For this reason, according to Mascarenhas et. al. (2013), the comprehension about volunteer motivation becomes relevant to all aspects of volunteer programmes.

According to Azevedo (2008), motivations such as altruism and solidarity, are labeled with volunteer spontaneous dedication, which most of the time, has been cause of some confusion with private and personal interests of improving résumé and professional experience. Yet, to the author, one possible cause to volunteer giving up would be the lack of clarity about motivations that make people to become volunteer.

To Salazar et. al. (2015), motivations to carry out activities related to volunteering, involves a high level of complexity. It reaches to the understanding that, to the volunteer, motivation dwells in the capacity of construction of a meaningful desire to promote social welfare, generating inner satisfaction to the individual.

Volunteer motivations are directly related to altruistic values that are characterized by attitudes based upon donation without nothing to be expected, showing that, according to Assis et.al. (2012), in volunteering, passion for the cause comes from a personal interest stronger than financial interest.

Other arguments about volunteer work motivation are presented by Palassi and Vervloet (2011) when they discuss the phenomenon of motivation by means of 
volunteer participation reasons. They argued that volunteer motivation bases resides in the feeling of taking part of something or transforming the environment. Volunteer participation, for many reason, like altruism or selfishness, must be analyzed as a way in which social needs are satisfied by the individual, as the valorization of oneself by others, social interaction and a thought ruled by the reflexion or in the aspect of social expression.

According to Anheier and Salamon (1999) understanding, there are three motivational factors that take people to be volunteers: altruistic, instrumental and obligatory motives. Altruistic motives include notions of solidarity feelings towards poor people, when volunteers identify themselves with people who suffer in the society and, for this reason, they seek to give hope and dignity by means of their work. Instrumental motives are defined as a desire to acquire new experiences and abilities and to do something valuable in their free time to assist people and also to obtain personal satisfaction as a volunteer. Finally, obligatory motives include moral and religious duty and a desire to contribute with local community configured by a feeling of political duty of bringing changes to society.

\section{VOLUNTEER MOTIVATION IN SPORT EVENTS}

According to Carvalho Segundo (2010), motivation to carry out any activity consists in a set of energetic forces that make the individual to start a behaviour related to the work and determines its strength, direction, intensity and duration. On the same way that motivation is one competence that refers itself to the reasons someone gets engaged in one specific activity. To many people taking part in one volunteering programme in sport events can be the entrance gate to work market, in which they can have the chance to discover new abilities and professional competences, develop leadership spirit and have a differential in curriculum (KOUTROU, 2014).

In sport events volunteers assume many functions like, for example: welcome spectators, security issues, technological support, medical assistance, among others. 
Therefore, initiatives are created with the intention to promote a new development policy in sport activities in Brazil that may be adequate to the new sport pattern.

\footnotetext{
"The advance of sport sector in Brazil ended by generating a series of discussions among sport scholars, undertaker, athletes, press and the civil society itself, about the role of public authority in the development of concrete actions that would be able to empower this sector of the economy in the country" (TADINI, 2007).
}

The carrying out of studies about volunteer motivation focused in sport events are relatively recent and they grow according to the increase of demand for volunteer workforce. Studies show that sport volunteers are motivated specially by their desire to help and contribute to the success of the event (OLIVEIRA and COSTA, 2016). Thus, satisfaction with volunteer work leans to be a determining important factor of commitment with the organizing entity of a certain sport event.

The carrying out of unpaid activities in sport events can be perceived as a personal satisfaction source once the person recognizes in motivation the main substance in ones dedication to perform the volunteer work. Therefore, when the main motivations of engaged people in volunteering are understood it becomes easier to managers to supply intrinsic needs of every individual.

In Koutrou's (2014) perspective, field research suggest that volunteers in sport events are motivated by a variety of factors, and the impact of these factors can vary considerably from one individual to another. Some volunteers may act altruistically, motivated by the desire to contribute to their community and to sport, while others try to acquire specific experience or pleasure, once volunteering can be beneficial in career development, in social network building and in the possibility to make friends. Therefore, this suggests that a combination of factors is necessary to explain volunteer behaviour in sport.

Research about volunteer motivation in sport, made public by Koutrou (2014), and carried out in the Olympics in London (2012), evidenced that predominant motivational factors were "love to sport", followed by "interpersonal contacts" factor, while "professional orientation" and "other rewards" were less prevailing to individual decisions of volunteers in the Olympic Games of London.

\section{EVENTUAL VOLUNTEERING IN SPORTS}


Literature about eventual volunteering emerges for the first time in the early 1990s, when Nancy Macduff (1991) suggested that there was a changing in the way people were becoming volunteers, giving their preference to short term volunteering opportunities rather than to traditional long term volunteering opportunities, what, according to Styers (2004), can be defined as eventual volunteering the participation of volunteers in sport events such as olympic games, characterizing this participation as eventual volunteering in sport.

Eventual work is the one made on transitory basis, in other words, it is made sporadically. To Lemos et. al.(2016), volunteering is not an easy task, since the person compromises oneself with one's abilities and knowledge in sport events organization, assuming many responsibilities that are assigned to him or herself without financial interest.

According to Tadini (2007), besides the socialization of participant teams with local community and the promotion of some type of hospitality to tourists that go to such type of events, sport events volunteer is also relevant to cut costs in the budget of organizing team to make the event possible. Once, sport is considered to be a social phenomenon of multiple possibilities that is useful to create the basis to other social works.

According to Teixeira and Bridi (2014), to eventual volunteer in sports, some of the motivations they have are, inner processes operation, competition special rules, arising the feeling of being part of the event, even by the opportunity to be in touch with athletes.

Experiences that eventual volunteers may receive for taking part in these sport events are related to positive experiences, such as, learning, knowledge exchange and personal growth. In this context, Lemos et. al. (2016) claims that volunteer involvement is crucial to make the event to be put into practice because without them the implementation would be much more onerous, besides a series of programmes targeted to leave a legacy at the venues of major events.

THEORETICAL MODEL (BANG and CHELLADURAI, 2009). 
Initial studies to the elaboration of this theoretical model, which addresses motivational aspects from volunteers in major sport events, started since Olympic Games in Athens (2004) and have been consolidated in the year 2009. Bang e Chelladurai (2009) indicated 6 (six) motivational factors in their studies, classified as: "expression of values": motivations related to altruístic reason, "interpersonal contacts": motivations related to relationships with other people, "career orientation": motivations related to acquiring experience and practical competences, "personal growth": motivations related to increasing self-esteem with experience, "extrinsic": motivation related to acquisition of advantages such as tickets and uniforms for free and "love to sport": motivations related to pleasure in participating in sport event. Figure 1, below, allows to have a better view of theoretical model structure.

Figura 1: Bang and Chelladurai (2009) Theoretical Model.

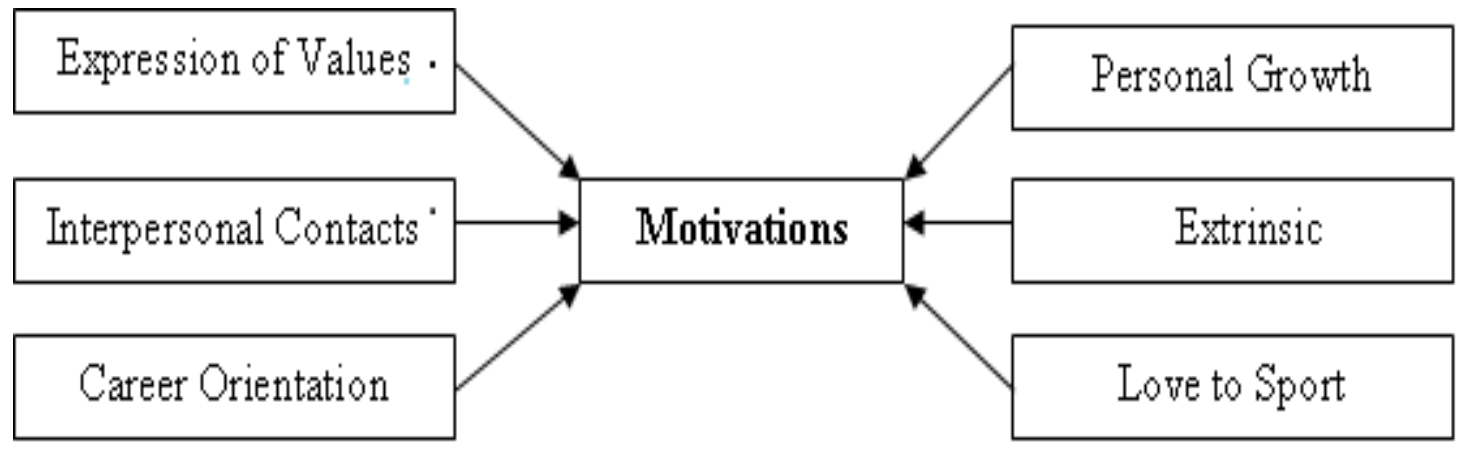

Source: Adapted by authors (2017), anchored in Bang and Chelladurai (2009) theoretical model.

\section{METHODOLOGY}

This research is of a descriptive character, since the moment it exposes volunteer motivational aspects involved in Youth School Games. Regarding to the approaching method, the research was based upon the quantitative character, insofar it evaluates volunteer motivations.

The sample universe consisted of 250 volunteers selected by the International Olympic Committee - IOC (2016). From this universe, questionnaires were applied with 167 volunteers. This sampling was defined by statistical method developed by Barbetta 
(2004), considering a confidence level of $95 \%$ in the development of the research, as it can be seen below:

$$
\begin{aligned}
& \text { no }=\mathbf{1} / \mathrm{Eo}^{2} \\
& \mathbf{n}=\mathbf{N} \text {. no / N + no, } \\
& \text { Being: } \\
& \mathrm{N} \text { - population size (number of elements); } \\
& n \text { - sample size (number of elements); } \\
& \text { no-first approximation of sample size; } \\
& \text { Eo }{ }^{2} \text { - tolerable sample error. } \\
& \text { no }=1 / \text { Eo }{ }^{2} \quad \rightarrow 0=1 /(0,05)^{2} \rightarrow n=400 \\
& n=N \text {. no / N + no } n \rightarrow 250.400 / 250+400 \rightarrow=167
\end{aligned}
$$

This sampling was selected from the probabilistic sampling method and organized by the stratified sampling method. To Barbetta (2004), stratified sampling is used when a população can be divided into homogeneous and random subpopulations, and it has the advantage of being more efficient than simple or systematic sampling methods, since it is more economic considering time and money, providing results with a minor error probability (BACELAR, 1999).

Concerning to data collection, it was used a research questionnaire proceeding from the theoretical model of Bang and Chelladurai (2009), in which eventual volunteer motivational aspects associated to sport events are identified. This data collection was performed in the venues of sport events, during Youth School Games held on João Pessoa city in the State of Paraíba.

To treat research data, statistic analyses have been carried out by means of measures related to sample mean, standard deviation, coefficient of variation, ANOVA and T-test. The standard deviation is a measure of dispersion of values in a normal distribution relating to its mean; in which is concerned the coefficient of variation, Pimentel Gomes (2000) says that, on field experiments, if the coefficient of variation is less than $10 \%$, it is understood that this coefficient of variation is low, that is, the 
experiment has high precision, from $10 \%$ to $20 \%$, they are considered mean and of good precision, from $20 \%$ to $30 \%$, high, with low precision, and, above $30 \%$, very high.

Table 1, below, refers to variables and descriptions of the research instrument used in this study.

Table 1: general view of volunteer motivational variables in sport events

\begin{tabular}{|c|c|c|}
\hline Variables & Description & Scale \\
\hline Motivations (Li & ert Scale: from 1 = Total disagreement to 10 = Total agreement) & \\
\hline Values 1 & I want to help in what is possible & Numeric \\
\hline Values 2 & I want to do something worthwhile & Numeric \\
\hline Values 3 & I feel it is important to help others & Numeric \\
\hline Values 4 & I want to help make the event a success & Numeric \\
\hline Values 5 & Volunteering helps creating a better society & Numeric \\
\hline Interpersonal 1 & I want to interact with other people & \\
\hline Numeric & & \\
\hline Interpersonal 2 & I want to work with different people & Numeric \\
\hline Interpersonal 3 & I want to meet and know new people & Numeric \\
\hline Interpersonal 4 & I want to develop relationship with others & Numeric \\
\hline Career 1 & To work as a volunteer will give a good impression to my curriculum & Numeric \\
\hline Career 2 & I want to acquire some practical experience & Numeric \\
\hline Career 3 & I want to make new contacts that may be helpful in my career & Numeric \\
\hline Career 4 & I want to acquire work experience & Numeric \\
\hline Career 5 & I want to acquire experiences that may be useful into any area & Numeric \\
\hline Growth 1 & Volunteering makes me feel needed & Numeric \\
\hline
\end{tabular}

Growth 2 I can explore my own potentialities Numeric

Growth $3 \quad$ Volunteering makes me feel important Numeric

Growth $4 \quad$ Volunteering allows one self to acquire a new perspective on everything

Numeric

Extrinsic 1 I want to acquire uniformes and licensed products Numeric

Extrinsic $2 \quad$ I want to acquire tickets and free pass $\quad$ Numeric

Sport $1 \quad$ I like an sport related event Numeric

Sport $2 \quad$ I like an sport event related to these sports 


\section{Future behaviours}

Future Event: I will get involved in another sport event in the future as a volunteer

\section{Sociodemographic Variables}

$\begin{array}{lll}\text { Gender } & \text { Participant gender }(1=\text { female, } 0=\text { male }) & \text { Fictitious } \\ \text { Age } & \text { Age (in years }) & \text { Metric } \\ \text { Education } & (1=\text { fundamental; } 2=\text { high school; } 3=\text { college } \\ & 4=\text { post-graduation }) & \text { Fictitious } \\ \text { Journey } & \text { How many working hours per week as a volunteer in the event? } & \text { Metric } \\ \text { Income } & \text { Monthly net income ( } 0=\text { no salary; } 1=\text { up to one salary, } & \text { Numeric } \\ 2=\text { between } 1 \text { and } 3 \text { salaries, } 3=\text { between } 3 \text { and } 5 \text { salaries, } 4=\text { above } 5 \text { salaries. } & \end{array}$

Source: Adapted by the authors (2017), based in the theoretic model of Bang and Chelladurai (2009)

\section{DISCUSSIONS AND ANALYSIS OF RESULTS}

Following it will be presented discussions and analysis of results of the research about eventual volunteer work motivation focused on sport during Youth School Games. This study used the theoretical model of Bang and Chelladurai (2009) as a way to identify volunteer motivation aspects on those who have been working during Youth School Games. It will be shown volunteer socio demographic data, future behaviour about participation and commitment of these volunteers in sport events and, finally, motivational factors that make volunteers to participate in these sport events. In the sequence, it is presented volunteer socio demographic profile. 
Volunteer socio demographic profile of those who have participated the research about volunteer work motivation in Youth School Games, showed the following characteristics, according to Chart 1 below.

Chart 1: Síntese sociodemográfica

\begin{tabular}{|c|c|c|}
\hline Variable & Class & Percentage \\
\hline \multirow{3}{*}{ Average age } & $18-28$ & $90 \%$ \\
\hline & $29-39$ & $8.46 \%$ \\
\hline & $40-50$ & $1.54 \%$ \\
\hline \multirow{5}{*}{ Average income } & No salary & $35.38 \%$ \\
\hline & up to 1 salary & $39.24 \%$ \\
\hline & Between 1 and 3 salaries & $17.69 \%$ \\
\hline & Between 1 and 5 salaries & $6.92 \%$ \\
\hline & Above 5 salaries & $0.77 \%$ \\
\hline \multirow{2}{*}{ Gender } & Male & $42.31 \%$ \\
\hline & Female & $57.69 \%$ \\
\hline \multirow{3}{*}{ Educational level } & University Students & $85 \%$ \\
\hline & Graduated & $10 \%$ \\
\hline & Post-Graduation & $5 \%$ \\
\hline
\end{tabular}




\begin{tabular}{|l|c|c|}
\hline \multirow{2}{*}{ Weekly working journey } & Between 1 and 10 hours & $2.31 \%$ \\
\cline { 2 - 3 } & Between 11 and 20 hours & $16.15 \%$ \\
\cline { 2 - 3 } & Between 21 and 30 hours & $22.31 \%$ \\
\cline { 2 - 3 } & Above 30 hours & $59.23 \%$ \\
\hline
\end{tabular}

Source: Research Data (2016)

From the data presented, it is possible to perceive some important characteristics to be highlighted, such as the greater participation of women as volunteers in the Games of the School of Youth. Other studies that addressed motivational aspects in sport, such as the one by Doherty (2005), Bang et al. (2008) and Hallmann and Harms (2012), presented divergent results regarding the greater voluntary participation of women in these events. Also noteworthy was the high number of university students who performed voluntary activities, in this event, totaling (85\%). This result differs from Pereira and Cavalcante's (2018) study at the Rio de Janeiro Olympic Games, which showed that $70 \%$ of the volunteers had a university degree or were postgraduates. It was also verified that the majority of volunteers (74.62\%) have an average family income of up to one salary, women (57.9\%) and young people (90\% with a maximum of 28 years).

There were some differences between the profiles of the volunteers who participated in the Olympic games in Rio de Janeiro, according to research by Pereira and Cavalcante (2018) and volunteers of the Youth Games. In the Olympic games the average age was 35 years, while in youth games it was a maximum of 28 years $(90 \%$ of the vountários). As for the monthly income of the volunteers, at the Olympic Games in Rio de Janeiro, the volunteers receive 4 salaries and in youth games, $74.62 \%$ of the volunteers receive a maximum of one salary.

Regarding the schooling of the volunteers, it was verified that in the Olympic games $70 \%$ of the volunteers had undergraduate or postgraduate degrees, while in the 
youth games, $85 \%$ were university students. The convergence in relation to the profile of the volunteers was similar in relation to the performance of the women in the two sporting events. At the Rio de Janeiro Olympic Games, $56 \%$ of the volunteers were women, and at youth games held in João Pessoa / PB, 57.69\% of the volunteers were also women.

Chart 2, following, shows the results referring to future behaviour about participation and engaging of these volunteers in sport events.

Chart 2: Volunteer future behaviours

\begin{tabular}{|c|c|c|}
\hline Variable & Options & Percentage \\
\hline \multirow{2}{*}{$\begin{array}{l}\text { Would like to participate as a } \\
\text { volunteer in other sport event }\end{array}$} & Yes & $91.54 \%$ \\
\hline & No & $8.46 \%$ \\
\hline \multirow{2}{*}{$\begin{array}{l}\text { Would like to associate as a } \\
\text { volunteer in a sport club in the } \\
\text { future }\end{array}$} & Yes & $48.46 \%$ \\
\hline & No & $51.54 \%$ \\
\hline
\end{tabular}

Source: Research Data (2016)

According to the results presented, it is observed that volunteers are inclined to participate in other sport events, however, they have no intention to associate with any sport club as a volunteer. Differently from this research performed during the Youth School Games, in other countries such as Germany, England, USA and Canada, there is, according to authors Breuer and Wicker (2011), Taylor et al. (2003) and Doherty (2005), a very high level of voluntary adhesion to sport clubs.

\section{EVENTUAL VOLUNTARY WORK MOTIVATION IN SPORTS}

Volunteer motivation analysis related to sports will be structured from the statistical measures related to the sample mean, standard deviation, coefficient of variation, and the analysis of motivational variable correlations referring to the 
theoretical model of Bang and Chelladurai (2009), "expression of values", "interpersonal contacts", "career orientation", "personal growth", "extrinsic" and "love to sport". Chart 3 , following, shows the statistical results referring to each variable.

Chart 3: Results of motivational variables

\begin{tabular}{|c|c|c|c|c|c|c|c|}
\hline Variable & Questions & $\begin{array}{c}\text { Average } \\
\text { per } \\
\text { Question }\end{array}$ & $\begin{array}{c}\text { Standard } \\
\text { Deviation } \\
\text { per } \\
\text { Question }\end{array}$ & $\begin{array}{c}\text { Coefficient of } \\
\text { Variation per } \\
\text { Question }\end{array}$ & $\begin{array}{l}\text { Variable } \\
\text { Average }\end{array}$ & $\begin{array}{l}\text { Variable } \\
\text { Standard } \\
\text { Deviation }\end{array}$ & $\begin{array}{c}\text { Variable } \\
\text { Coefficient of } \\
\text { Variation }\end{array}$ \\
\hline \multirow{5}{*}{$\begin{array}{l}\text { Expression } \\
\text { of Values }\end{array}$} & 1 & 9.33 & 1.76 & $18.86 \%$ & \multirow{5}{*}{9.39} & \multirow{5}{*}{1.24} & \multirow{5}{*}{$13.20 \%$} \\
\hline & 2 & 9.56 & 1.59 & $16.63 \%$ & & & \\
\hline & 3 & 9.61 & 1.03 & $10.72 \%$ & & & \\
\hline & 4 & 9.55 & 1.36 & $14.24 \%$ & & & \\
\hline & 5 & 8.89 & 1.95 & $21.93 \%$ & & & \\
\hline \multirow{4}{*}{$\begin{array}{l}\text { Interpersona } \\
\text { I Contacts }\end{array}$} & 1 & 9.04 & 1.42 & $15.71 \%$ & \multirow{4}{*}{8.89} & \multirow{4}{*}{1.38} & \multirow{4}{*}{$15.52 \%$} \\
\hline & 2 & 8.96 & 1.59 & $17.74 \%$ & & & \\
\hline & 3 & 8.9 & 1.34 & $15.06 \%$ & & & \\
\hline & 4 & 8.65 & 1.56 & $18.03 \%$ & & & \\
\hline \multirow{5}{*}{ Career } & 1 & 8.67 & 1.75 & $20.18 \%$ & \multirow{5}{*}{9.05} & \multirow{5}{*}{1.42} & \multirow{5}{*}{$15.69 \%$} \\
\hline & 2 & 9.25 & 1.44 & $17.57 \%$ & & & \\
\hline & 3 & 9.05 & 1.34 & $14.81 \%$ & & & \\
\hline & 4 & 9.27 & 1.19 & $12.84 \%$ & & & \\
\hline & 5 & 9.01 & 1.31 & $14.53 \%$ & & & \\
\hline \multirow{4}{*}{$\begin{array}{l}\text { Personal } \\
\text { Growth }\end{array}$} & 1 & 8.78 & 1.56 & $17.77 \%$ & \multirow{4}{*}{8.64} & \multirow{4}{*}{1.64} & \multirow{4}{*}{$18.98 \%$} \\
\hline & 2 & 9 & 1.08 & $12 \%$ & & & \\
\hline & 3 & 8.41 & 1.83 & $21.76 \%$ & & & \\
\hline & 4 & 8.36 & 1.88 & $22.49 \%$ & & & \\
\hline \multirow{3}{*}{ Extrinsic } & 1 & 5.47 & 2.97 & $54.30 \%$ & \multirow{2}{*}{5.39} & \multirow{2}{*}{2.96} & \multirow{2}{*}{$54.91 \%$} \\
\hline & 2 & 5.32 & 2.95 & $55.45 \%$ & & & \\
\hline & 1 & 8.63 & 1.83 & $21.20 \%$ & 8.39 & 2 & $23.84 \%$ \\
\hline
\end{tabular}




\begin{tabular}{|c|c|c|c|c|}
\multirow{3}{*}{$\begin{array}{c}\text { Love to } \\
\text { Sport }\end{array}$} & 2 & 7.64 & 2.35 & $30.76 \%$ \\
\cline { 2 - 5 } & 3 & 8.6 & 1.84 & $21.39 \%$ \\
\cline { 2 - 6 } & 4 & 8.68 & 1.77 & $20.39 \%$ \\
\end{tabular}

Source: Research Data (2016)

Data presented in Chart 3 show that the highest volunteer motivational level who worked during the youth games are related to the variable "expression of values" and the lowest motivational level is related to factors of "extrinsic" variable.

Following, motivational variables will be analysed individually from the motivational order reported on Chart 3.

Chart 4: Motivational variable "expression of values"

\begin{tabular}{|c|c|c|c|c|c|c|c|}
\hline Variable & Questions & $\begin{array}{l}\text { Question } \\
\text { Average }\end{array}$ & $\begin{array}{l}\text { Question } \\
\text { Standard } \\
\text { Deviation }\end{array}$ & $\begin{array}{c}\text { Question } \\
\text { Coefficient of } \\
\text { Variation }\end{array}$ & $\begin{array}{l}\text { Variable } \\
\text { Average }\end{array}$ & $\begin{array}{c}\text { Variable } \\
\text { Standard } \\
\text { Deviation }\end{array}$ & $\begin{array}{c}\text { Variable } \\
\text { Coefficient of } \\
\text { Variation }\end{array}$ \\
\hline \multirow{5}{*}{$\begin{array}{c}\text { Expression of } \\
\text { Values }\end{array}$} & 1 & 9.33 & 1.76 & $18.86 \%$ & \multirow{5}{*}{9.39} & \multirow{5}{*}{1.24} & \multirow{5}{*}{$13.20 \%$} \\
\hline & 2 & 9.56 & 1.59 & $16.63 \%$ & & & \\
\hline & 3 & 9.61 & 1.03 & $10.72 \%$ & & & \\
\hline & 4 & 9.55 & 1.36 & $14.24 \%$ & & & \\
\hline & 5 & 8.89 & 1.95 & $21.93 \%$ & & & \\
\hline
\end{tabular}

Source: Research Data (2016)

Motivational variable "expression of values", constituted by five questions found in the research tool, showed an average of (9.39), standard deviation of (1.24) and coefficient of variation of (13.20\%), what characterizes a homogeneous sample, of good precision and very close to the average, not showing dispersion in the answers presented by the researched volunteers.

"Expression of values" is the more altruistic motivational variable from Bang and Chelladurai (2009) theoretical model because it is related to motivational aspects, like: to feel important in helping others, to help creating a better society and to contribute 
to the sport event to become a success. This variable presented the highest average (9.39) among all the others analysed, leading to the understanding that the greatest motivational aspect from volunteers in Youth School Games is "expression of values", which helds altruistic characteristics.

Hallmann and Harms (2012) study, which evaluated volunteer motivational aspects in national games of handball and horsemanship in Germany, presented similar results to the one identified in this research in which the variable "expression of values" it was the main volunteer motivation factor in these sport events.

Following, it will be reported the results referring to motivational variable "interpersonal contacts".

Chart 5: Motivational variable "interpersonal contacts"

\begin{tabular}{|c|c|c|c|c|c|c|c|}
\hline Variable & Questions & $\begin{array}{l}\text { Question } \\
\text { Average }\end{array}$ & $\begin{array}{l}\text { Question } \\
\text { Standard } \\
\text { Deviation }\end{array}$ & $\begin{array}{c}\text { Question } \\
\text { Coefficient of } \\
\text { Variation }\end{array}$ & $\begin{array}{l}\text { Variable } \\
\text { Average }\end{array}$ & $\begin{array}{l}\text { Variable } \\
\text { Standard } \\
\text { Deviation }\end{array}$ & $\begin{array}{c}\text { Variable } \\
\text { Coefficient of } \\
\text { Variation }\end{array}$ \\
\hline \multirow{4}{*}{$\begin{array}{c}\text { Interpersonal } \\
\text { Contacts }\end{array}$} & 1 & 9.04 & 1.42 & $15.71 \%$ & \multirow{4}{*}{8.89} & \multirow{4}{*}{1.38} & \multirow{4}{*}{$15.52 \%$} \\
\hline & 2 & 8.96 & 1.59 & $17.74 \%$ & & & \\
\hline & 3 & 8.9 & 1.34 & $15.06 \%$ & & & \\
\hline & 4 & 8.65 & 1.56 & $18.03 \%$ & & & \\
\hline
\end{tabular}

Source: Research Data (2016)

Data presented in Chart 5 set motivational variable "interpersonal contacts" with third highest average among motivational aspects in the research. This variable is constituted by four questions found in the research tool and presented an average (8.89), standard deviation (1.38) and coefficient of variation (15.52\%), thus, verifying a consistent result of a sample with characteristics of homogeneity, good precision and the majority of presented answers was very closed to the verified average in the variable.

This variable is related to motivational aspects related to volunteer interaction with other people, availability to work with different people, get to know new people and to develop relationship with other people. It presented the average (8.89), indicating the third highest volunteer motivational factor in the school games, verifying 
that interpersonal development is an important motivational factor to volunteers in the Youth School Games.

Filo et al. (2012) study, which presented a scale about volunteers motivation in sports, in the USA, showed similar results to the ones identified in this research. In the research performed in the USA, volunteer motivational aspects, related to interpersonal relationship, as well as in the school games, presented the third highest motivational factor reported by volunteers.

Following, it will be described data referring to motivational variable "career orientation".

Chart 6: Motivational variable "Career development"

\begin{tabular}{|c|c|c|c|c|c|c|c|}
\hline Variable & Questions & $\begin{array}{l}\text { Question } \\
\text { Average }\end{array}$ & $\begin{array}{l}\text { Question } \\
\text { Standard } \\
\text { Deviation }\end{array}$ & $\begin{array}{l}\text { Question } \\
\text { Coefficient } \\
\text { of Variation }\end{array}$ & $\begin{array}{l}\text { Variable } \\
\text { Average }\end{array}$ & $\begin{array}{l}\text { Variable } \\
\text { Standard } \\
\text { Deviation }\end{array}$ & $\begin{array}{c}\text { Variable } \\
\text { Coefficient } \\
\text { of Variation }\end{array}$ \\
\hline \multirow{5}{*}{ Career development } & 1 & 8.67 & 1.75 & $20.18 \%$ & \multirow{5}{*}{9.05} & \multirow{5}{*}{1.42} & \multirow{5}{*}{$15.69 \%$} \\
\hline & 2 & 9.25 & 1.44 & $17.57 \%$ & & & \\
\hline & 3 & 9.05 & 1.34 & $14.81 \%$ & & & \\
\hline & 4 & 9.27 & 1.19 & $12.84 \%$ & & & \\
\hline & 5 & 9.01 & 1.31 & $14.53 \%$ & & & \\
\hline
\end{tabular}

Source: Research Data (2016)

Motivational variabel "career orientation" is related to the way volunteer activities in sport can contribute to the development of volunteer professional career. From the results presented by this motivational variabel, it is observed that it obtained the second highest among the other six variables researched. It is constituted by five questions found in the research tool and presented average (9.05), standard deviation (1.42) and coefficient of variation (15.69\%). The result of this variable shows a consistent result, with characteristics of homogeneity, good precision and low dispersion among the answers of the volunteers subjected to the research.

With an average (9.05), this motivational variable constitutes the second highest volunteer motivational factor in the school games, observing that career development 
is a relevant motivational factor to the volunteers that worked during Youth School Games.

Bang and Ross (2009) study, which presented a scale about volunteer motivation in sports, in Greece, showed similar results to the one identified in this research. In the research performed in Greece, volunteer motivational aspects related to career development, differently from school games, presented the fifth highest motivational factor reported by volunteers.

Following, it will be described data referring to motivational variable "personal growth".

Chart 7: Motivational variable "Personal Growth"

\begin{tabular}{|c|c|c|c|c|c|c|c|}
\hline Variable & Questions & $\begin{array}{l}\text { Question } \\
\text { Average }\end{array}$ & $\begin{array}{l}\text { Question } \\
\text { Standard } \\
\text { Deviation }\end{array}$ & $\begin{array}{c}\text { Question } \\
\text { Coefficient of } \\
\text { Variation }\end{array}$ & $\begin{array}{l}\text { Variable } \\
\text { Average }\end{array}$ & $\begin{array}{l}\text { Variable } \\
\text { Standard } \\
\text { Deviation }\end{array}$ & $\begin{array}{c}\text { Variable } \\
\text { Coefficient of } \\
\text { Variation }\end{array}$ \\
\hline \multirow{4}{*}{$\begin{array}{l}\text { Personal } \\
\text { Growth }\end{array}$} & 1 & 8.78 & 1.56 & $17.77 \%$ & \multirow{4}{*}{8.64} & \multirow{4}{*}{1.64} & \multirow{4}{*}{$18.98 \%$} \\
\hline & 2 & 9 & 1.08 & $12 \%$ & & & \\
\hline & 3 & 8.41 & 1.83 & $21.76 \%$ & & & \\
\hline & 4 & 8.36 & 1.88 & $22.49 \%$ & & & \\
\hline
\end{tabular}

Source: Research Data (2016)

Data exposed in Chart 7 set motivational variable "personal growth", constituted by four questions, found in the research tool, as the fourth highest average compared to the other six variables researched. This variable has the average of (8.64), standard deviation (1.64) and coefficient of variation (18.98\%). This result characterizes a homogeneous sample, of good precision and very close to the average, not showing dispersion in the answers presented by researched volunteers.

"Personal growth" motivational variabel is related to the following aspects: feeling good about being a volunteer, development of volunteer potentialities and to feel important to be a volunteer. With an average (8.64), this motivational variable constitutes the fourth highest volunteer motivational factor in the olympic games, verifying, thus, that personal growth is not considered one of main factors that led volunteers to participate in the Youth School Games. 
The same study by Bang et al. (2008), which defined a scale about volunteer motivation in sports, in Greece, presented similar results to the ones identified in this research. In the research in Greece, volunteer motivational aspects related to personal growth, such as the ones in school games, showed the fourth highest motivational factor reported by volunteers.

Following, it will be described data referring to "extrinsic" motivational variable.

Chart 8: Motivational variable "Extrinsic"

\begin{tabular}{|c|c|c|c|c|c|c|c|}
\hline Variable & Questions & $\begin{array}{c}\text { Question } \\
\text { Average }\end{array}$ & $\begin{array}{c}\text { Question } \\
\text { Standard } \\
\text { Deviation }\end{array}$ & $\begin{array}{c}\text { Question } \\
\text { Coefficient of } \\
\text { Variation }\end{array}$ & $\begin{array}{c}\text { Variable } \\
\text { Average }\end{array}$ & $\begin{array}{c}\text { Variable } \\
\text { Standard } \\
\text { Deviation }\end{array}$ & $\begin{array}{c}\text { Variable } \\
\text { Coefficient of } \\
\text { Variation }\end{array}$ \\
\hline \multirow{2}{*}{ Extrinsic } & 1 & 5.47 & 2.97 & $54.30 \%$ & 5.39 & 2.96 & $54.91 \%$ \\
\cline { 2 - 7 } & 2 & 5.32 & 2.95 & $55.45 \%$ & & \\
\hline
\end{tabular}

Source: Research Data (2016)

"Extrinsic" motivational variable presented as the lowest volunteer motivation among those who participated in the Youth School Games. This variable is constituted by two questions in the research questionnaire and it is related to the acquisition of material and licensed products in the sport event, such as to receive freely tickets to follow the event. In the perspective of Bang e Chelladurai (2009) theoretical model, this variable has the highest selfish motivation among the other six variables researched.

With average (5.39), standard deviation (2.96) and coefficient of variation (54.91\%), it is possible to conclude that volunteers who have participated in school games have no selfish motivation. It is worthy to highlight that coefficient of variation presented a relatively high result, which characterizes this sample as one of low precision with dispersion in among the answers. Hallmann and Harms (2012) study in sports events in Germany presented similar results to this study, once "extrinsic" motivational variable was the lowest motivational aspect presented by volunteers in both research.

Following, it will be reported the results referring to motivational variable "love to sport". 
Chart 9: Motivational variable "Love to Sport"

\begin{tabular}{|c|c|c|c|c|c|c|c|}
\hline Variable & Questions & $\begin{array}{l}\text { Question } \\
\text { Average }\end{array}$ & $\begin{array}{l}\text { Question } \\
\text { Standard } \\
\text { Deviation }\end{array}$ & $\begin{array}{c}\text { Question } \\
\text { Coefficient of } \\
\text { Variation }\end{array}$ & $\begin{array}{l}\text { Variable } \\
\text { Average }\end{array}$ & $\begin{array}{c}\text { Variable } \\
\text { Standard } \\
\text { Deviation }\end{array}$ & $\begin{array}{c}\text { Variable } \\
\text { Coefficient of } \\
\text { Variation }\end{array}$ \\
\hline \multirow{4}{*}{ Love to sport } & 1 & 8.63 & 1.83 & $21.20 \%$ & \multirow{4}{*}{8.39} & \multirow{4}{*}{2.0} & \multirow{4}{*}{$23.84 \%$} \\
\hline & 2 & 7.64 & 2.35 & $30.76 \%$ & & & \\
\hline & 3 & 8.6 & 1.84 & $21.39 \%$ & & & \\
\hline & 4 & 8.68 & 1.77 & $20.39 \%$ & & & \\
\hline
\end{tabular}

Source: Research Data (2016)

From the results verified in Chart 9, it is highlighted that this variable presented the fifth volunteers motivational factor that worked in school games. With average (8.39), standard deviation (2) and coefficient of variation (23.84\%), it is verified that this sample has a good average, low data dispersion and good reliability, characterizing that motivational variable "love to sport" it is not very relevant in motivational terms to volunteers who worked in Youth School Games.

This variable has four questions found in the research questionnaire and has relation to the volunteers affinity and disposition to participate in sports events. Doherty (2005) study about motivation in volunteer work in sport clubs in Canada, thus as in school games, showed the fifth motivational factor reported by volunteers, in what is related to motivational variable "love to sport".

Following, it will be reported the results about socio demographic data and the difference among groups.

\section{ANALYSES BETWEEN SOCIO DEMOGRAPHIC DATA AND THE DIFFERENCE AMONG GROUPS}

In this item it will be approached aspects related to the difference between groups statistically meaningful and socio demographic data found in the research tool certified by the theoretical model developed by Bang and Chelladurai (2009). 
Following, it will be reported the difference between gender and the variable "sport is something that I love (sport 3)".

Table 2: Difference between gender x "sport 3" groups

\begin{tabular}{lcc}
\hline Difference between groups & Average to women & Average to men \\
\hline Gender x Sport 3 & 8.9 & 7.6 \\
& & \\
\hline
\end{tabular}

Source: Research Data (2016)

It is verified, by the data presented in Table 2, and taking into consideration aspects related to variable "sport 3", found in the research tool, that, in average, women are more inclined to be volunteers in sports events because they like sport more than men. Van Schien et al. (2014) and Pereira and Cavalcante (2018) studies, who researched volunteer work in sports events in Swiss and in the Olympic Games of Rio de Janeiro, respectively, displayed that women participate more in sports events in volunteer work than men.

From data presented, it is possible to subsidise managers of sports events to concentrate major efforts in recruiting women to these events, taking into consideration the particularity of each individual sport activity.

Following, it will be reported the difference among $\mathrm{x}$ age variable groups "personal growth 3".

Table 3: Differences between age variable x "personal growth 3" groups

\begin{tabular}{lcc}
\hline Difference between groups & $18-28$ years & $40-50$ years \\
\hline Age x "personal growth 3" & 7.4 & 8.75 \\
\hline
\end{tabular}

Source: Research Data (2016) 
It is observed, by results presented in Table 3 that make the relation between volunteers age and the variable "personal growth 3" from the research tool, that oldest ones are inclined to feel more important in the development of volunteer activities than the young ones.

To Souza and Lautert (2008), volunteer work for oldest people, make them feel more important, contributing to enhance their physical and mental health. Oldest people look, in volunteer work, among other factors, one opportunity to be more useful to society. In this sense, oldest volunteers would be very useful in sports events in activities in which they would feel important to the event.

Following, it will be reported the difference among groups of $x$ age variable "career 4".

Table 4: Differences between age variable x "career 4" groups

Difference between groups 18-28 years above 50 years

\begin{tabular}{lll}
\hline Age x "career 4" & 6.2 & 3.58
\end{tabular}

Source: Research Data (2016)

Variable "career 4" talks about the disposition volunteers have to acquire work experience. In this sense, results presented in Table 4 show that younger volunteers are more inclined to be volunteers in sport to acquire some practical work experiences, if compared to oldest ones.

According to Gravilov (2012), young people look to develop volunteer activities as a way to learn something. As a consequence of these results, managers of sports events could put the younger volunteers in activities in which they would offer a practical experience, like works related to the area of computing of competition, thus as the ones offered in the Media Center and in the logistic area of the event.

Following, it will be reported the difference among $x$ school level variable groups "career 5".

Table 5: Differences between school level variable x "career 5" groups 


\begin{tabular}{lcc}
\hline Difference between groups & High school & post-graduated \\
\hline school level x "career 5" & 7.70 & 5.80
\end{tabular}

Source: Research Data (2016)

"Career 5" variable reveals aspects related to the possibility that the volunteer be able to acquire experience that may be useful in any professional area. It is perceived, from the results presented, that volunteers with high school are more inclined to understand that volunteer activity in sport, is able to allow them to acquire important professional experience more than volunteers with post graduation educational level.

It can be concluded, therefore, that people who have post graduation understand that volunteer work activities in a sport event are not able to explore their potentialities as a whole. According to Walton (1973) theoretical model, which approaches aspects related to work life quality, there are some characteristics that are related to the exploration of employees potentialities, that means: meaning of accomplished task, identity with the task and abilities variety.

In the presence of this aspect, it might exist a comprehension from the managers of these events, in the sense of setting volunteers place from a previous analyses of their experiences and capacities, in the development of volunteer activities, in a way that it may make possible a wider learning acquisition, especially, to those volunteers that who have high school level.

Following, it will be reported the difference among the income $x$ "expression of values 5" variable groups.

Table 7: Differences between income variable x "expression of values 5" groups

Difference between groups no salary 1-3 salaries
Income $x$ values 5
8.75
6.9 
Source: Research Data (2016)

In the presence of data presented and taking "expression of values 5 " variable as the reference, found in the research tool, it is concluded that, in average, sport volunteers who have no income are more inclined to say that volunteer work helps to create a better society.

Pereira and Cavalcante (2018) study, in the Olympic Games of Rio de Janeiro, it is also concluded, that, volunteers who have no income, claim that volunteer work may contribute to the society as a whole. This result shows that it is more profitable to managers of sport events to recruit volunteers to sport activities among those who have no income because they understand that volunteer activity helps in the creation of a better society, in comparison to volunteers who have 1 to 3 salaries.

\section{FINAL CONSIDERATIONS}

The target of this study was to identify eventual volunteers motivational factors involved in sports events in the state of Paraíba. Knowledge about voluntary motivation is essential in the process of recruiting volunteers in sports events, helping organizers of these events to identify characteristics between volunteers interests and abilities with their activities in sports events.

According to the results from the research, it was possible to conclude that major volunteer motivations who worked during Youth School Games are related to "expression of values" variables, which have an altruistic bias, "career" and "love to sport". Presenting the minor volunteer motivational factor it was identified the "extrinsic" variable, which has a selfish character in terms of voluntary motivation.

It was observed, yet, more strict results about the research, that will be described in the sequence: women are more inclined to be volunteers in sports events than men; oldest people are more inclined to feel more important in the development of volunteer work; youngest people are more inclined to become volunteers in sports events to acquire professional experience in any activity area; volunteers with a lower educational grade are more inclined to understand that volunteer activity may help HOLOS, Ano 35, v.7, e7411, 2019 
them to acquire practical experience; and volunteers who have no income are more inclined to claim that volunteer work contributes to make a better society.

Main limitation of this study is related to the quantity of volunteers subjected to the research. Comrey and Lee (1992) classified, in relation to the factorial analyses, samples of 50 as very inferior, of 100 as inferior, of 200 as razonable, of 300 as good, of 500 as very good and of 1,000 or plus as excelents.

About future studies, it is recommended that research may be performed with volunteers in other sports events, in another states of Brazil that may be used as a comparative to understand volunteers motivational aspects that work in these sports events.

\section{REFERENCES}

ANHEIER, H. K. E SALAMON, L. M. (1999). “Volunteering in cross-national perspective: Initial comparation". Law and contemporary problems, 62(4): 43-66.

ANNAN, C. SPORT CONGRESS. Congresso Internacional Voluntariado. Laussane, p. 4, 2001.

AÑÒ, V. The importance of volunteering in a great event: The program of Almería 2005. Actas Del Congresso Internacional Andalucia Tierra Del Desporte. Sevilha, v. 2, Ministry of Tourism and Sports, 2003.

BACELAR, S.M. (1999). Sampling in the social sciences - theoretical-practical class report. Porto, Portugal.

BANG, H. \& CHELLADURAI, P. (2009). Development and validation of the volunteer motivations scale for international sporting events (VMS-ISE). International Journal of Sport Management, 6, 332-350.

BANG, H., \& ROSS, S. (2009). Volunteer motivation and satisfaction. Journal of venue and Event Management, 1, 61-77. 
BARBETTA, P.A. (2004). Statistics Applied to Social Sciences, 5. ed. Florianópolis: Publisher of UFSC. BARELI, P; LIMA, A. J. F. S. The social importance in the development of voluntary work. Management sciences journal: v. 14, n. 20, year 2010.

BONJEAN, CHARLES M., WILLIAM T. MARKHAM, and PATRICK O. MACKEN, (1994). "Measuring Self-Expression in Volunteer Organizations: A Theory-Based Questionnaire." Journal of Applied Behavioral Science, 30 (4), 487-515. BREUER, C. and WICKER, P. (2011). "Situation und entwicklung des freiwilligen engagements und ehrenamts in sportverein "In: Breuer, C. (Org.) sportenwicklungsbericht 2009/2010 - Analysezur situation der sportvereine in Deuschland, sportveilogstraub, koln, p. 91-111.

BRUNO, B. FIORILLO, D. (2012). Why without pay? Intrinsic motivation in the unpaid labour supply. Journal of Socio-Economics 41: 659-669.

CNAAN, R.A.; CASCIO, T. Performance and commitement issues in managment of volunteers in human service organizations, journal of social service research, vol. 24, no 314, pp. 1-37, 1998.

CAVALCANTE, C.E. motivation in volunteer work. expectations and motives in the pastoral care of children. PhD thesis, Graduate Program in Administration, Federal University of Rio Grande do Norte, Natal, 2012.

COI (2016). Disponível em: < https://editorolimpico.wordpress.com/2015/06/28/aevolucao-dos-voluntariados-olimpicos-e-o-conceito/, acessado em 10/11/2016.

DOHERTY, A. (2005). A profile of community sport volunteers/volunteer management in community sport clubs. Toronto: parks and recreation Ontario/ sport alliance of Ontario.

FALEIROS, E. T. S. The child and the adolescent: object without value in Brazil colony and in the empire. In: The Art of Governing Beliefs: The History of Social Policies, 
Legislation and Child Care in Brazil, Rio de Janeiro: Editora Universidade Santa Úrsula, 1995.

FARRELL, J. M., JOHNSTON, M. E., \& TWYNAM, D. G. (1998).Volunteer motivation, satisfaction, and management at an elite sporting competition. Jornal of Sport Management, $12,288-300$.

FIFA (2014). Disponível em: <http://www.brasil.gov.br/esporte/2012/09/programa-devoluntarios-da-copa-2014-recebeu-mais-de-130-mil-inscricoes >, acessado em 10/11/2016.

FILO K., GROZA MD, Fairley S. The role of belief in making a difference inenhancing attachment to a charity sport event. J Nonprofit Public SectorMark 2012, 24 (2): 123140.

GRAVILOV, G. (2012). Managing sport event volunteers: London 2012 Olympic Games Marers.

HALLMANN, K.; HARMS, G. (2012). "Determinants of volunteer motivation and their impact on future voluntary engagement: A comparison of volunteer's motivation at sport events in equestrian and handball." International Journal of Event and Festival Management, v. 3, iss 3, p. 272-291.

JOHNSTON, M., E., TWYNAM, D. G., \& FARRELL, J. M. (1998). Motivation and satisfaction of event volunteers for a major youth organization . Leisure/Loisir, 24 (12), 161-177.

KOUTROU, NIKI (2014). Measuring Olympic Volunteers' Motivations. Intersections and Intersectionalities in Olympic and Paralympic Studies, p. 55-61.

LATHSM, G.P., Pinder, C.C. Work Motivation Teory and research at the dawn of the twenty-first century. Annual review of psychology, 56, 485-516, 2005.

MACDUFF, NANCY (1991). Episodic Volunteering: Building the Short-Term Volunteer Program. WallaWalla, WA: MBA Publishing. 
MORAGAS, M. Evolution of the Olympic Volunteers in the Olympic Games. In: MC ALOON, John. Volunteers, Global Society and the Olympic Moviment. Simpósio Internacional. Laussane, 2001.

PALASSI, M. P., \& VERVLOET, A. M. P. (2011). Elections, syndicates and subjectivity: reflections on the production of subjective meanings from voluntary participation in the voting process. Psychology and Society, 23 (2), 312-324.

PAULA, E. DE. Good success. Interpersonal relations and quality of life at work. Rio de Janeiro: Quality Mark Ed., 2002.

Pereira, H.A; Cavalcante, C. E. Gold medal! Study on motivation in an eventual volunteer work in the Olympic Games in Rio de Janeiro. Organizations in context, São Bernardo do Campo, ISSNe 1982-8756 • Vol. 14, n. 28, jul-dec. 2018.

PEREIRA, P. A. P. Discussões conceituais sobre política social como política pública e direito de cidadania. In: Política Social no Capitalismo: Tendências Contemporâneas. São Paulo: Cortez, 2008.

PIMENTEL GOMES, F. Curso de Estatística Experimental, 14. ed. Piracicaba Desgapari, 200, 477p.

BRAZILIAN MAGAZINE (2015). Available at: <http://www.ebc.com.br/cidadania/2015/09/emprego-saiba-como-o-travelvoluntario-pode-valorizar-o-e-curriculo>, accessed on 08/03 / 2017

RUBIN, A., \& THORELLI, I. M. (1984). Egoistic motives and longevity of participation by service volunteers. Journal of Applied Behavioral Science, 20 (3), 223-235.

STYERS, D. (2004).Volunteering for success. Australian Journal on Volunteering, 9 (2), 84-86.

TADINI, R. F. Volunteering in Special Sport Events in Brazil: An Analysis of Volunteer Training Promoted by the Brazilian Olympic Committee. XXX Brazilian Congress of Communication Sciences - Santos - August 29 to September 2, 2007. 
TAMAYO. A. PASCHOAL, T. Impact of labor values and family interference: work on occupational stress. Psic .: content. and pesq., n.21, v.2, may 2005

TAYLOR, P., NICHOLS, G., HOLMES, K., JAMES, M., GRATTON, C., GARRETT, R., KOKOLAKAKIS, T., MULDER, C., \& KING, L. (2003). Sports volunteering in England. London: Sport England.

VAN SCHIE S., GUNTERT ST, OOSTLANDER J. et al. How the organizational context impacts volunteers: a differentiated perspective on self-determined motivation. Int Soc Third Sector Res 2014.

WALTON, R. Quality of working life: what is it? Slow Management Review. USA, v. 15, n. 1, p. 11-21, 1973.

WANG, C. L., \& WU, X. (2014). Volunteers' motivation, satisfaction, and management in large-scale events: an empirical test from the 2010 shanghai world expo. voluntas, $25,754-771$. 